\title{
Mechanistic Insight of Water Stress Induced Aggregation in Wheat (Triticum aestivum L.) Quality: The Protein Paradigm Shift
}

\author{
Ijaz Rasool NOORKA', Jaime A. TEIXEIRA da SILVA² \\ ${ }^{1}$ University of Sargodha, University College of Agriculture, Department of Plant Breeding and Genetics, Sargodha, Pakistan; ijazphd@yahoo.com \\ ${ }^{2}$ Kagawa University, Faculty of Agriculture and Graduate School of Agriculture, Department of Horticultural \\ Science, Miki-cho, Ikenobe 2393, Kagawa-ken, 761-0795, Japan; jaimetex@yahoo.com
}

\begin{abstract}
Vertical and horizontal expansion of agriculture to provide food, feed, fibre and fuel to escalating populations has affected the availability of wheat in terms of quantity and quality. Irrigation is the most important factor influencing yield and grain quality. To achieve sustainable and quality wheat production, strategic measures should be adopted. Seven water stress-tolerant wheat varieties/ strains were crossed with drought-susceptible lines using a line $\times$ tester design to evaluate the effect of water stress on genetic variability and heritability of wheat grains. As might be expected, plant traits like moisture, ash, fat, protein and gluten content showed different responses under normal irrigated and water-stress environments. In particular, the quality of wheat grains was found to be highly significant, indicating the presence of high variability in plant attributes like moisture percentage, ash content, crude fat, crude protein percentage and gluten content under both normal irrigation and water stress conditions. Water stress played a key role in reducing the moisture and fat content, whereas correspondingly, it increased protein, ash and gluten contents. The paradigm shifts in the deleterious effects of water stress have been elucidated. The broad-sense heritability estimate was significant for each of these characters under both conditions, with water stress in some measurements altering the heritabilities of all quality characters.
\end{abstract}

Keywords: heritability, protein, quality, variability, water stress

\section{Introduction}

Climate change and global warming has the potential to damage all natural resources and agriculture. Most of the world economy is predominantly agrarian with wheat being in prime position among all crops due to its staple food status. According to the FAO (2009), increasing food production to meet the Millennium Development Goal (MDG), by which huger has to be defeated by 2015, is going out of reach. On a nutritive note, wheat per capita availability for 170 million people of Pakistan is 140.88 $\mathrm{kg}$ per annum (GOP, 2010). Water stress seriously hurts wheat yield potential that might well decline half as much, compared to irrigated areas (GOP, 2010). The position of wheat is crucial in daily food consumption due to its absolute baking performance in contrast to all other cereals (Dewettinck et al., 2008) and is the best source for feeding humans (Mesbah, 2009)

Most of the Pakistani population lives in rural areas and mainly consumes wheat in the form of flat breads (chapatti, naan, roti) which sufficiently fulfill their dietary needs in this region; the same can be said for most of the Indian sub-continent and parts of Africa (Dhingra and Jood, 2001; Nurul-Islam and Johansen 1987). Wheat is the cheapest source of daily caloric and nutritional requirements but declining water availability represents a threat to food supply around the world (Zwart and Bastiaanssen, 2004). Wheat breeder's prime objective is to improve wheat yield under contrasting conditions of water availability. With changing food habits, breeders are paying greater attention to improving quality characteristics of this food staple. The quality of wheat products depends upon the quality of the grain (Al-Karaki, 2012; Finney et al., 1987), thus wheat quality axiomatically affects the quality of flat breads (Rehman et al., 2006). Irrigation water and fertilizer play an elementary role in the viscoelastic properties of gluten (Rehman et al., 1997). Protein quality and quantity both have a role in chapatti making and in end production (Prabhasankar, 2002). Global climatic changes and a rise in temperature is a threat for phenology, growth and yield of wheat (Hossain and Teixeira da Silva, 2012). Ultimately, increasing water shortages have diverted the world's attention to evolving water stress-tolerant crop varieties. Due to water stress, wheat yield, as well as the quality of wheat, is affected (Ahmad and Arain, 1999; Mahboob et al., 2005; Moharram and Habib, 2011). So, the time has come to improve water availability on one hand, and on the other to evolve wheat varieties that can withstand water stress without compromising quality. Wheat genotypes are now classified on quality traits so that traders can sell wheat according to the needs of millers, bakers and other end users 
(Morris, 2002). A pre-requisite for selection is to create types of combinations such that genetic variability can be ensured. Noorka and Khaliq (2007) reported genotypic variability in wheat under water stress conditions. Similarly, others (Chowdhry et al., 1999; Hakim et al., 2012; Marry et al., 2001; Noorka et al., 2009) studied genetic variability of wheat genotypes in relation to water stress.

Heritability is the ability and power of a character to transmit its behavior from one generation to the next. The knowledge of heritability helps the plant breeder in predicting the behavior of succeeding generations. The higher the heritability, the simpler will be the selection process, and thus the greater the response to selection. Heritability does not depend only upon genetic factors but also on environmental circumstances. Of course, environment-related performance is not heritable.

The present study attempts to assess to what extent a wheat breeder and agronomist might succeed in developing new stress-tolerant strains of wheat with the genetic materials in hand.

\section{Materials and methods}

The study was conducted at the Department of Plant Breeding and Genetics, University of Agriculture, Faisalabad, during the 2006-2007 and 2007-2008 seasons. Seven water stress-tolerant wheat genotypes, including two exotics viz., 'Nesser' and 'Dharwar Dry', and five local varieties viz. 'GA-2002' 'Bakhar-2002', 'Chakwal', 'Inqilab-91' and 'Kohistan-97' were crossed with University drought susceptible lines viz. 9244, 9247, 9252, 9258, 9267, 9316 and 9021 . The line $\times$ tester mating design, as described by Kempthorne (1957), was used. $F_{1}$ seeds along with 14 parents were sown in two experiments using a randomized complete block design (RCBD) with three replications. As part of the planned treatment, normal irrigation was applied to one plot throughout the reproductive phase of the crop, while the other plot was subjected to water stress. At maturity, the data were collected and subjected to analysis of variance (ANOVA) (Steel et al., 1997). Yield was determined in the best yielding genotypes, namely, 'Nesser,' 'Dharwar Dry', 'Nesser' $\times$ 9244, 'Nesser' $\times$ 9316, 'Nesser' $\times$ 9252, 'Dharwar Dry' $\times 9267$, 'Dharwar Dry' $\times$ 9316, 'Dharwar Dry' $\times$ 9252, 'GA-2002' × 9252 and 'Inqilab-91' $\times 9316$ from normal as well as water stressed conditions. The strength grade of flour of each genotype was evaluated for their proximate composition such as moisture contents (AACC Method, 44-15A), ash content, (AACC 08-01) crude fat (AACC 30-25), crude protein (AACC Method 46-13) and nitrogen percentage in the grains was determined using the micro Kjeldahl method as described by Peter and Young (1980) while gluten content (AACC 38-10) was determined according to the methods described in AACC (2000). The estimates of broad-sense heritability (h2BS) were calculated for both normal irrigation and water stress conditions with the formula: $\mathrm{h} 2(\mathrm{BS})=\sigma 2 \mathrm{~g} / \sigma 2 \mathrm{p}$

and standard errors (SE) of broad-sense heritability were calculated by using the formula as given by Lothrop et al. (1985):

$$
\mathrm{SE}(\mathrm{h} 2 \mathrm{BS})=\frac{\text { S.E. ó } 2 \mathrm{~g}}{\text { ó } 2 \mathrm{p}}
$$

\section{Results and discussion}

Drought is a complex phenomenon which involves dynamic interactions of soil, plant, and atmosphere continuum. In the present study variation exhibited by five quality traits under both normal irrigation and water stress conditions played an effective role in developing drought-tolerant genotypes. Most of the traits under study such as moisture percentage, ash content, crude fat, crude protein and gluten content showed significant variability among parents (lines and testers) and their hybrids, which suggested the possibility of selecting a promising best genotype or a cross combination to further improve the population under study. The global water crisis is a severe threat for sustainable agriculture, particularly in most of the Asian countries (Huaqi et al., 2002). Farmers and researchers are striving hard to find out appropriate means to dwindling water consumption in wheat production systems. To improve some of the problems currently facing Pakistani crop improvement programs, including limited water at the seedling stage, mid-season water stress, terminal stress or any combination of these. Ten high-yielding wheat genotypes were selected from normal irrigation conditions and their respective crosses under water stressed conditions. Under water stress condition, the trait moisture content decreased significantly while other traits predominantly protein contents increased in the entire crosses showing a great variation in quality traits (Noorka et al., 2009).

\section{Paradigm shift in wheat quality traits due to water stress}

In the present study, water stress played a pivotal role in altering normal growth of wheat. Furthermore, water stress reduced most of the characters, ultimately reducing economic yield. Plant traits are, in general, reduced in response to water stress (Moharram and Habib, 2011; Nabipour et al.2002).

In dealing with quality parameters, the wheat breeder is faced with many complex factors. A wheat variety suitable for one purpose may be unsatisfactory for another (Halverson and Zeleny, 1988). Wheat flour is extensively used for production of flat breads such as chapatti a source of nutrients and is a staple diet common to Pakistan, India and some parts of Africa (Nandini and Salimath, 2001). In this study, water stress decisively changed the normal quality measures of wheat. Furthermore, water stress reduced economic yield, percentage moisture and crude fat while increasing ash content, crude protein and gluten contents. These results are a stark contrast to what is usually found, 
34

i.e. a reduction in most quality-related traits and represents showing a shift in paradigm shift in the normal in which it is conventionally thought that water stress always has a deleterious effect on crop production, exemplified by the increase in quality traits like ash content (8.33 to $27.09 \%$ ), crude protein (1.49 to $16.00 \%)$ and gluten content $(5.40$ to $12.11 \%$ ) (Tab. 1), although variance was high (Tab. 2, 3). Ahmad and Arain (1999) and Guttien et al. (2001) also showed a contradictory simultaneous reduction and addition of plant traits in response to water stress. A detailed discussion based on quality traits follows next.

\section{Moisture content}

Moisture content is a very important quality character in terms of storage of wheat grains for definite periods before it is rendered fit for use; lower flour moisture implies better storage quality and stability and wheat grains with high moisture content due to normal irrigation are difficult to store and vulnerable to pest and diseases (Pomeranaz and Williams, 1990). An alternative form of storage is oven drying which is un-natural and may damage the proteins (Gooding and Davies, 1997). Under normal irrigation condition the moisture contents ranged from 11.82-11.39\% while under water stress condition it ranged from $11.63-10.90 \%$ showing a significant decrease in each genotype. Due to water stress, moisture content percentage decrease ranged from $4.72 \%$ ('Nesser') to $0.34 \%$ ('Dharwar Dry' $\times$ 9252) (Tab. 1) which would be beneficial for wheat grain long-term storage. Other researchers reported a range of moisture content in wheat grain from 12.09-11.78\% (Din et al., 2007) and 13.45\% (Rehman et al., 2007) under normal irrigation conditions.

\section{Fat content}

The fat content in wheat flour plays an important role during the baking process. It has a significant role in the holding capacity of gas during fermentation and is also an excellent source of energy (Pasha, 2006). Under normal irrigation condition the fat contents ranged from 2.33-2.15 while under water stress condition fat content ranged from 1.92-1.63 showing a significant decrease in each genotype. Crude fat decreased under water stress, ranging from $9.00 \%$ in 'Nesser' to $25.22 \%$ in the cross combination 'Inqilab-91' $\times 9316$ (Tab. 1). A wide range of fat content in wheat has been reported earlier under normal irrigation conditions ranging from 2.93 to 1.74 (Taneja et al., 1983), 1.2 (Raymond, 1993), and 1.35 (Rehman et al., 2007).

\section{Ash content}

Ash is the mineral residue remaining after a sample has been completely oxidized in a manner such that all organic volatile material is driven off, while preventing any mineral from being lost (Ponser, 1991). Whole wheat flour is rich in mineral elements since $80 \%$ of the total amount of minerals is concentrated in the aleuron layer of the pericarp (bran) while about $20 \%$ is present in the endosperm. Rao et al. (1986) recommended flour containing 10.6\% protein, $8 \%$ moisture and $1.45 \%$ ash content for making chappati. Ash content is a measure of purity and quality of wheat flour. It does not affect the baking quality but shows different levels of bran depending on the variety. Under normal irrigation condition the ash contents ranged from 1.83-1.55 while under water stress condition ash content ranged from 2.06-1.88 showing a significant increase in each genotype. The ash content increased maximum up

Tab. 1. Percent decrease in wheat quality traits due to water stress conditions

\begin{tabular}{|c|c|c|c|c|c|}
\hline Genotypes & $\begin{array}{l}\text { Percent decrease } \\
\text { in moisture stress }\end{array}$ & $\begin{array}{l}\text { Percent decrease } \\
\text { in fat }(\%)\end{array}$ & $\begin{array}{c}\text { Percent increase } \\
\text { in ash (\%) }\end{array}$ & $\begin{array}{l}\text { Percent increase } \\
\text { in protein }(\%)\end{array}$ & $\begin{array}{l}\text { Percent increase } \\
\text { in dry gluten }(\%)\end{array}$ \\
\hline 'Nesser' & 4.72 & 9.00 & 8.99 & 11.14 & 7.90 \\
\hline 'Dharwar Dry' & 1.49 & 17.64 & 11.11 & 16.00 & 8.19 \\
\hline 'Nesser' × 9244 & 3.80 & 19.45 & 14.44 & 14.75 & 5.40 \\
\hline 'Nesser' × 9316 & 4.27 & 17.60 & 8.33 & 3.90 & 8.60 \\
\hline 'Nesser' $\times 9252$ & 2.04 & 16.21 & 27.09 & 5.47 & 7.89 \\
\hline 'Dharwar Dry' × 9267 & 3.91 & 19.53 & 18.49 & 4.41 & 6.85 \\
\hline 'Dharwar Dry' × 9316 & 3.13 & 23.21 & 22.07 & 9.10 & 6.21 \\
\hline 'Dharwar Dry' × 9252 & 0.34 & 21.05 & 7.65 & 5.25 & 12.11 \\
\hline 'GA-2002' × 9252 & 0.86 & 18.77 & 14.68 & 1.49 & 6.16 \\
\hline 'Inqilab-91' × 9316 & 3.41 & 25.22 & 16.57 & 9.33 & 8.88 \\
\hline
\end{tabular}

Tab. 2. Analysis of variance of quality traits in ten wheat genotypes under normal irrigation conditions

\begin{tabular}{ccccccc}
\hline Source of variation & d.f. & Moisture & Crude protein & Crude fat & Ash content & Gluten content \\
\hline Replication & 2 & 0.001 & 0.060 & 0.004 & 0.000 & $0.140 \mathrm{NS}$ \\
Genotypes & 9 & $0.061^{* *}$ & $0.986^{* *}$ & $0.014^{* *}$ & $0.032^{* *}$ & $0.814^{* *}$ \\
Error & 18 & 0.002 & 0.048 & 0.003 & 0.000 & 0.018 \\
\hline
\end{tabular}

Significant at $p<0.05^{* *}$; Significant $p<0.01 ; \mathrm{NS}=$ Non significant 
Tab. 3. Analysis of variance of quality traits in ten wheat genotypes under water stress conditions

\begin{tabular}{ccccccc}
\hline Source of variation & d.f. & Moisture & Crude protein & Crude fat & Ash content & Gluten content \\
\hline Replication & 2 & 0.002 & 0.047 & 0.001 & 0.000 & $0.142 N S$ \\
Genotypes & 9 & $0.132^{* *}$ & $0.428^{* *}$ & $0.026^{* *}$ & $0.012^{* *}$ & $1.135^{* *}$ \\
Error & 18 & 0.001 & 0.025 & 0.002 & 0.003 & 0.022 \\
\hline
\end{tabular}

Significant at $p<0.05^{* *}$ Significant $p<0.01 \mathrm{NS}=$ Non significant

to $27.09 \%$ in case of cross between 'Nesser' $\times 9252$ and minimum $7.65 \%$ in 'Dharwar Dry' $\times 9252$ although there was scarcity of water (Tab. 1). Other researchers reported a range of ash contents in different wheat varieties under normal irrigation conditions from 0.50-0.45 (Raymond, 1993), 0.48 (Nadeem et al., 2004) and 0.80 (Rehman et al., 2007). However, Seleiman et al. (2011) revealed that ash content increased under water stress conditions from 1.78 to 1.87 .

\section{Protein content}

Protein content is of prime importance in wheat quality and wheat flour. Dry and sunny weather as well as water stress favor maximum production of protein in wheat grain. Kent and Evers (1994) reported that protein contents in wheat are affected by genetic as well as nongenetic factors e.g., soil, climate and fertilizer application. Under normal irrigation condition the protein contents ranged from 11.2-13.78\% while under water stress condition it ranged from 12.47-13.92\% showing a significant increase in each genotype. Water shortage depicted a paradigm shift by showing a significant increase in protein content percentage ranging from 16.00 to $1.49 \%$ (Tab. 1) in genotype 'Dharwar Dry' and a cross combination 'GA-2002' × 9252, respectively. Similar results have been reported by Singh et al. (2008) and Naseri et al. (2010) who revealed that with the effect of water stress the protein content in wheat increased protein contents by $10.3-13.2 \%$ while Seleiman et al. (2011) reported that less irrigation and water stress increased protein content by $11.20 \%-13.40 \%$ in first year while $13.00 \%-14.10 \%$ in second year. Under normal irrigation conditions $10.82 \%$ protein content was reported by Butt et al. (1997) while Randhawa et al. (2002) reported food crude protein content as $11.82 \%$. Similarly, $10.2 \%$ protein content was reported by Nadeem et al. (2004) and $11.71 \%$ by Din $e t$ al. (2007) under normal irrigation. Ozturk and Aydin (2004) also reported that water stress increased grain pro- tein content by $18.1 \%$, sedimentation volume by $16.5 \%$, and wet gluten content by $21.9 \%$.

\section{Gluten content}

Gluten content is a very important trait for the assessment of flour quality. The unique properties of endospermic protein are called gluten. Gluten does not exist as an entity in whole wheat grain or in flour; it is only produced when flour is physically and vigorously mixed with water (Rehman, 1987).Strong dough is suitable for bread making while weak dough is suitable for cookies (Gaines, 1990). The visco-elastic properties of gluten proteins affect the quality of bread gluten (Veraverbeke and Delcour, 2002). Under normal irrigation condition the gluten contents ranged from 15.24-13.67 while under water stress condition it ranged from 16.18-14.75 showing a significant increase in each genotype. Water stress played a positive role once again and increased gluten content percentage, ranging from 12.11 to $5.40 \%$ in the cross combinations 'Dharwar Dry' $\times 9252$ and 'Nesser' $\times 9244$, respectively (Tab. 1). These results are in line with earlier research by Seleiman et al. (2011), who reported that due to six irrigation gluten content was 10.40 and 11.9 in two consecutive years while under water stress the gluten content has been increased up to 13.10 in the first year and 13.5 in the second year. Similarly, Lin et al. (2003) reported 7.0 and 16.77 and Pasha et al. (2007) 4.46 and 14.55 while Curic (2001) reported 8.44 and 11.77 and Din et al. (2007) 8.72 and 10.69 under normal irrigation conditions.

\section{Heritability}

Heritability clarifies whether the differences among variables are due to genetic make up or due to environmental variations and serves as the principal tool to estimate the latent value for an assortment of desired traits. Farshadfar et al. (2000) reported that high broad-sense heritability estimates indicated a preponderance of the additive variation in the total genetic variability while medium to low

Tab. 4. Estimates of phenotypic variance $\left(\sigma^{2} \mathrm{p}\right)$, genotypic variance $\left(\sigma^{2} \mathrm{~g}\right)$ and broad sense heritability under normal irrigation conditions

\begin{tabular}{ccccc}
\hline Characters & $\sigma^{2} \mathrm{p}$ & $\sigma^{2} \mathrm{~g}$ & $\sigma^{2} \mathrm{e}$ & Heritability \\
\hline Moisture \% age & 0.021 & 0.019 & 0.002 & 0.907 \\
Ash content & 0.010 & 0.010 & 0.000 & 1.000 \\
Crude fat & 0.006 & 0.036 & 0.003 & 0.550 \\
Crude protein \% age & 0.360 & 0.312 & 0.048 & 0.866 \\
Gluten content & 0.283 & 0.265 & 0.018 & 0.936 \\
\hline
\end{tabular}


Tab. 5. Estimates of phenotypic variance $(\sigma 2 \mathrm{p})$, genotypic variance $(\sigma 2 \mathrm{~g})$ and broad sense heritability under water stress conditions

\begin{tabular}{ccccc}
\hline Characters & $\sigma^{2} \mathrm{p}$ & $\sigma^{2} \mathrm{~g}$ & $\sigma^{2} \mathrm{e}$ & Heritability \\
\hline Moisture \% age & 0.040 & 0.040 & 0.001 & 0.980 \\
Ash content & 0.006 & 0.003 & 0.003 & 0.500 \\
Crude fat & 0.010 & 0.008 & 0.002 & 0.800 \\
Crude protein \% age & 0.150 & 0.130 & 0.030 & 0.840 \\
Gluten content & 0.390 & 0.370 & 0.020 & 0.940 \\
\hline
\end{tabular}

heritability suggests that environmental effects accounted for a major portion of total phenotypic variation.

Estimates of genetic variance for quality traits under normal irrigation and water stress conditions

The present study revealed that the values for phenotypic variance were greater than those for genotypic variance for all five traits under both normal irrigation (Tab. 4) and water stress conditions (Tab. 5) except for crude fat under normal irrigation conditions. The broad-sense heritability was significant for all characters under both normal irrigation and water stress.

Under normal irrigation condition, the broad-sense heritability estimates for moisture percentage (90.7\%), ash content $(100 \%)$, crude fat $(55 \%)$, crude protein $(86.6 \%)$ and gluten content (93.6\%) (Tab. 4) while under water stress condition the broad-sense heritability values fluctuated, depicting a paradigm shift in heritable frequency of traits. As is evident from Tab. 5, the heritability values for moisture percentage remained (98\%), ash content (50\%), crude fat $(80 \%)$, crude protein $(84 \%)$ and gluten content (94\%). In this sense, the higher the heritability value, the easier the selection process since if the heritability value of a trait is low than the selection of that phenotype will not be fruitful and the breeder should rather consider progeny testing; however, when values of heritability are high, phonotypical selection will be more effective.

The aforementioned estimates exercised significant effect on the physio-chemical properties as well as genetic heritabilities of the genotypes under study. Significant differences in quality traits, under both normal irrigation and water stress conditions are in accordance with the findings of Farshadfar et al. (2000), who reported a range of high, medium and low hertibilities in wheat under normal irrigation conditions; however, Cox et al. (1989) were of the view opinion that any decline and deterioration in the quality of wheat might be due to non-genetic factors such as changes in the environment. The water stress seemed to may have played a significant role in reducing the moisture and fat content of grain while concurrently increasing protein, ash and gluten contents as compared under to normal irrigation conditions. As for heritability, Rana et al. (1999) and Farshadfar et al. (2000) reported that high value of broad-sense heritability estimates denoted a preponderance of additive variation in the total genetic variability while medium to low heritability suggests that environmental effects accounted for the major part of total phenotypic variation. It is therefore suggested that potential genotypes and their crosses identified in this study should be studied further to assess the stability of characters under a wider range of environmental stresses for the future breeding programs in order to meet both the quantitative and qualitative needs of wheat production throughout the world.

\section{Acknowledgement}

The authors thank Prof Dr Abdur Rahman (Ex-Vice Chancellor University of Agriculture, Faisalabad, Pakistan) and Akbar Hossain (Wheat Research Center, Bangladesh Agricultural Research Institute) for valuable input during research and critique of the paper.

\section{References}

AACC (2000). Approved methods of American Association of Cereal Chemists. The American Association of Cereal Chemists. Inc., St. Paul. MN.

Ahmad M, Arain MA (1999). Effect of drought simulation on grain weight, protein and lysine content of bread wheat. Pak J Bot 31(1):109-114.

Al-Karaki GN (2012). Phenological development-yield relationships in durum wheat cultivars under terminal high temperature stress in semiarid conditions. International Scholarly Research Network. ISRN Agronomy. Article ID 456856, 7 p. Available online: http://www.isrn.com/journals/agronomy/2012/456856/.

Butt MS, Anjum FM, Rehman A, Ali A (1997). Physiochemical characteristics of spring wheat. J. Agri. Res. 35(4):413-422.

Chowdhry MA, Rasool I, Khaliq I, Mahmood T, Gilani MM (1999). Genetics of some metric traits in spring wheat under normal and drought environments. Rachis 18(1): 34-38.

Cox TS, Shogren MD, Sears RG, Martia TJ, Bolte LC (1989). Genetic improvement in milling and baking quality of hard red winter wheat cultivars from 1919 to 1987 . Crop Sci 29:626-631.

Curic D (2001). Gluten as a standard of wheat flour quality. Food Tech Biotech 39(4):353-361.

Dewettinck K, Van Bockstaele F, Kuhne B, Van de Walle D, Courtens TM, Gellynck X (2008). Nutritional value of bread: Influence of processing, food interaction and consumer perception. J Cereal Sci 48:243-257.

Dhingra S, Jood S (2001). Organoleptic and nutritional evalu- 
ation of wheat breads supplemented with soybean and barley flour. Food Chem 77:479-488.

Din GM, Rehman SU, Anjum FM, Nawaz H (2007). Quality of flat bread (naan) from Pakistani wheat varieties. Pak J Agric Sci 44(1):171-175.

FAO (2009). The State of Food Security in the World. Rome. Available at: www.fao.org

Farshadfar E, Farshadfar M, Sutka J (2000). Combining ability analysis of drought tolerance in wheat over different water regimes. Acta Agron Hungarica 48(4):353-361.

Finney KF, Yamazaki WT, Youngs VL, Rubenthaler GL (1987). Quality of hard, soft and durum wheats, 667-748 p. In: Heyne EG (Ed.). Wheat and Wheat improvement, Agronomy Monograph, No. $132^{\text {nd }}$ ed., Madison WI: American Society of Agronomy.

Gaines CS (1990). Influence of chemical and physical modification of soft wheat protein on sugar snap cookie dough consistency, cookie size and hardness. Cereal Chem 67:73 77.

Gooding MJ, Davies WP (1997). Wheat production and utilization; system, quality and environment, CAB Int., Wallingford, UK.

Government of Pakistan (2010). Economic Survey of Pakistan, Finance Division, Government of Pakistan, Finance Division, Government of Pakistan, Islamabad.

Guttien MJ, Stark JC, O’Brien K, Souza E (2001). Relative sensitivity of spring wheat grain yield and quality parameters to moisture-deficit. Crop Sci 41:327-335.

Hakim MA, Hossain A, Teixeira da Silva JA, Zvolinsky VP, Khan MM (2012). Yield, protein and starch content of 20 wheat (Triticum aestivum L.) genotypes exposed to high temperature under three sowing conditions. J Sci Res 4(2):477-489.

Halverson J, Zeleny L (1988). Criteria of wheat quality, 15-46 p. In: Pomeranz Y (Ed.). Wheat Chemistry and Technology, American Association of Cereal Chemist. Inc., St Paul, $\mathrm{MN}$.

Hossain A, Teixeira da Silva JA (2012). Phenology, growth and yield of three wheat (Triticum aestivum L.) varieties as affected by high temperature stress. Not Sci Biol 4(3):97109.

Huaqi W, Bouman BAM, Zhao D, Changgui W, Moya PF (2002). Aerobic rice in northern China: Opportunities and challenges. Workshop on water wise rice production, 8-11 April IRRI, Los Baños, Philippines.

Kempthrone D (1957). Introduction to genetics statistics. John Willy and Sons Inc., New York.

Kent NL, Evers AD (1994). Technology of Cereals. 4th Ed., Pergamon Press, Oxford.

Lin P, Chiang SH, Chang CY (2003). Comparison of rheological properties of dough prepared with different wheat flours. J Food Drug Anal 11(3):220-225.

Lothrop JE, Arkins RE, Smith OS (1985). Variability for yield and yield components in IAPIR grain sorghum random mating population. I. Means, variance components and heritabilities. Crop Sci 25:235-240.

Mahboob AS, Arain MA, Khanzada S, Naqvi MH, Dahot MU, Nizamani NA (2005). Yield and quality parameters of wheat genotypes as affected by sowing dates and high temperature stress. Pak J Bot 37(3):575-584.

Mesbah EAM (2009). Effect of irrigation regimes and foliar spraying of potassium on yield and yield component and water use efficiency of wheat (Tricticum aestivum L.) in sandy soil. World J Agric Sci 5(6):662-669.

Moharram J, Habib M (2011). Evaluation of 10 wheat cultivars under water stress at Moghan(Iran) condition. African J Biotech 10(53):10900-10905.

Morris CF (2002). Puroindolines: The molecular genetic basis of wheat grain hardness. Plant Mol Biol 48:633-647.

Nabipour AR, Yazdi-Samadi B, Zali AA, Poustini K (2002). Effects of morphological traits and their relations to stress susceptibility index in several wheat genotypes. BIBAN 7(1):31-47 [Pl. Br Absts 3(6):5957, 2003]

Nadeem MT, Anjum FM, Rehman SU (2004). Effect of different additives and packaging materials on shelf life of bread. Indus J Plant Sci 3(1):125-129.

Nandini CD Salimath PV (2001). Carbohydrate composition of wheat, wheat bran, sorghum and bajra with good chapatti/roti (Indian flat bread) making quality. Food Chem 73:197-203.

Naseri R, Soleimanifard A, Soleimani R (2010). Yield and yield components of dry land wheat cultivars as influenced by supplementary irrigation at different growth stages. AmEurasian J Agric Environ Sci 7(6):684-689.

Noorka IR, Khaliq I (2007). An efficient technique for screening wheat (Triticum aestivum L.) germplasm for drought tolerance. Pak J Bot 39(5):1539-1546.

Noorka IR, Rehman SU, Haidry JR, Khaliq I, Tabassam S, Din $M$ (2009). Effect of water stress on physico-chemical properties of wheat (Triticum aestivum L.). Pak J Bot 41(6):29172924.

Nural-Islam MD, Johanson HB (1987). Physical chemical tests-a basis of selecting the size of wheat flour. J Food Sci Tech 24:136-145.

Ozturk A, Aydin F (2004). Effect of water stress at various growth stages on some quality characteristics of winter wheat. J Agron Crop Sci 190(2):93-99.

Pasha I (2006). Biochemical characterization of Pakistani wheats in relation to grain hardiness. Ph.D. Thesis, Inst. Food Sci. Tech. Univ. Agric. Faisalabad, Pakistan.

Pasha I, Anjum FM, Butt MS, Sultan JI (2007). Gluten quality prediction and correlation studies in spring wheats. J Food Qual 30:438-449.

Peter LP, Young VR, (1980). Nutritional Evaluation of Protein Foods. The United Nations University, Japan, 8 p.

Pomeranaz Y, Williams PC (1990). Wheat hardness: Its genet- 
38

ic, structural and biochemical background, measurement and significance, 471-548 p. In: Pomeranaz Y (Ed.). Advances in Cereal Science and Technology, Vol. X, American Association of Cereal Chemists, Inc. St. Paul. MN

Ponser ES (1991). Wheat and flour ash as a measure of mill ability. Cereal Food World 36(8):626-629.

Prabhasankar P (2002). Electropherotic and immunochemical characteristics of wheat protein fractions and their relationships to chapatti-making quality. Food Chem 78:81-87.

Rana V, Sharma SC, Sethi V (1999). Comparative estimates of genetic variation in wheat under normal and drought stress conditions. J Hill Res 12(2):92-94 [Pl. Br Absts 70(5):4624; 2000]

Randhawa MA, Anjum FM, Butt MS (2002). Physiochemical and milling properties of new spring wheat grown in Pun$\mathrm{jab}$ and Sindh for the production of pizza. Int J Agric Biol $4(4): 482-484$.

Rao H, Leelavathi PK, Shurpalehar SR (1986). Test baking of chapatti-development of a method. Cereal Chem 63:297303.

Raymond C (1993). Flour description and definitions. The bread bakers guide of America News Letter Vol. 1.

Rahman A (1987). Manual of wheat breeding procedures. FAO of the UN Rome, Italy.

Rehman S, Paterson A, Piggott JR (1997). Quantification of total flour protein and its relation to rheological characteristics related to chapatti. Sci Int 9:55-59.
Rehman S, Paterson A, Piggott JR (2006). Optimisation of chapatti textural quality using British wheat cultivar flours. Int J Sci Food Tech 41(suppl 2):30-36.

Rehman SU, Peterson A, Hussain S, Murtaza MA, Mehmood $S$ (2007). Influence of partial substitution of wheat flour with vetch (Lathyrus sativus $\mathrm{L}$.) flour on quality characteristics of doughnuts. LWT Food Sci Tech 40(1):73-82.

Seleiman M, Abdel-AAl S, Ibrahim M, Zahran G (2011). Productivity, grain and dough quality of bread wheat grown with different water regimes. J Agron Crop Sci 2(1):1117.

Singh S, Singh G, Singh P, Singh N (2008). Effect of water stress at different stages of grain development on the characteristics of starch and protein of different wheat varieties. Food Chem 108(1):130-139.

Steel RGD, Torrie JH, Dickey DA (1997). Principles and procedures of statistics: A biometrical approach. $3^{\text {rd }}$ ed. McGraw Hill Co., Inc., New York, USA.

Taneja S, Gupta K, Wagle DS, Dhinda KS (1983). Biological evaluation of wheat varieties. J Food Sci Tech 20:319-320.

Veraverbeke WS, Delcour JA (2002). Wheat protein composition and properties of wheat glutenin in relation to breadmaking functionality. Rev Food Sci Nutr 42(3):179-208.

Zwart SJ, Bastiaanssen WGM (2004). Review of measured crop water productivity values for irrigated wheat, rice, cotton and maize. Agric Water Management 69(2):115-130. 